\title{
The Effect of Problem Based Learning Model on Understanding Concepts and Problem Solving Skill in Social Sciences in Grade IV Students of SDN 1 Mulung Driyorejo Gresik
}

\author{
Miftaqul Rizqi Muliyono, a, Totok Suyanto 1,b, Muhammad Turhan Yani1,c \\ ${ }_{1}^{1}$ Postgraduate, State University of Surabaya, Surabaya, Indonesia \\ a rizqi.miftaqul@gmail.com; b totoksuyanto@unesa.ac.id; c mturhanyaniyani@yahoo.co.id; \\ ${ }^{*}$ Corresponding Author \\ Whatssap Number [085735907922]
}

How to Cite : Muliyono, M., R., Suyanto, T., \& Yani, M., T. (2019). The Effect of Problem Based Learning Model on Understanding Concepts and Problem Solving Skill in Social Sciences in Grade IV Students of SDN 1 Mulung Driyorejo Gresik. International Journal for Educational and Vocational Studies, 1 (3), 229-235.

\section{ARTICLE HISTORY}

Received: 12 May 2019

Revised: 17 June 2019

Accepted: 19 July 2019

\section{KEYWORDS}

Problem Based Learning, Understanding Concepts, Problem Solving Skills

\section{ABSTRACT}

This study aims to determine whether the use of the problem-based learning model can influence the understanding of concepts and problem-solving skills in social studies learning in the fourth grade of SDN 1 Mulung. This study uses a quantitative method with quasi-experimental design type nonequivalent sampled group design. The dependent variable in this study is the understanding of concepts and problem-solving skills, and the different variables are problem-based learning models. The sample chosen in this study uses namely IV-A class students totaling 20 students and IV-B class students totaling 20 students, using the sample random sampling technique. Data collection techniques using tests (pre-test and post-test). The research instrument used was a test sheet for understanding concepts and problem-solving skills. Instrument analysis technique uses validity test and reliability test while the data analysis technique uses the normality test, homogeneity test, hypothesis test, and normalized n-gain test. Based on the calculation of the T-test, Sig. (2-tailed) That is equal to $0,000<0,05$, then $\mathrm{Ha}$ is accepted, or there are significant differences between the difference between the results of the post-test and pre-test of the control class with the difference between the results of the post-test and the pre-test of the experimental class. This can be interpreted that the problem-based learning model has a significant effect on the understanding of concepts and problem-solving skills in social studies learning in the fourth grade of SDN 1 Mulung on natural resource material. To provide effective, interesting, and fun learning for students, teachers, should use an interesting learning model.

This is an open access article under the CC-BY-SA license.

\section{INTRODUCTION}

Social Sciences (IPS) as one of the subjects obtained by Elementary School Students (SD) that must be taught to elementary students has many concepts that are still abstract in nature such as the concepts of space, change, continuity, ritual, acculturation, value and role. Seeing how many abstract concepts exist in social studies learning, it is undeniable that social studies subjects are still lessons that sometimes cause problems in learning, namely students' low understanding. Judging from the IPS material which contains facts, concepts, and generalizations, it does require a large portion in the aspect of understanding. Moreover, IPS is oriented towards the establishment of a democratic and responsible society. By understanding concepts, students can take advantage of the knowledge gained in everyday life.

But in reality, there is a significant gap between what is expected and the reality that appears in the class. Students are asked to understand all IPS subject material well by just reading all the reading texts in the handbook. While the teacher just holds on to the handbook and sits quietly without doing anything to help students in learning in class, where learning activities should be needed that are more than just reading to support students' knowledge and understanding. In line with what was stated by Dwason in Muliyono (2017: 2) that a teacher cannot expect his students to be able to understand concepts, how to evaluate and use learning resources just by reading.

The material consists of many concepts and students are only asked to memorize it to understand it, so students who are good at memorizing their learning outcomes will be good and other students learning outcomes will be less or below the Minimum Completion Criteria (KKM). According to Andriansen (2012: 2) a teacher needs to break down the social studies learning process into the purpose of its preparation, analyze the problems and misunderstandings 
of students in relation to learning objectives and create activities designed to overcome problems in learning.

This is directly proportional to what Rini said (2017: 1741) that so much IPS material will make students easily bored in the learning process, and when understanding the material students are only asked to memorize it, so students who have difficulty memorizing results learning will be lacking or brought by the KKM. Regarding students, concepts such as curiosity, need, motivation, skepticism and investigation, research, and investigation need to be regulated during learning. Studies conducted on permanent education and flexible learning with these elements show that passive acceptance of students must change and students must have their own learning responsibilities. The purpose of education must be to increase the creative, exploratory and natural instincts of students and to make students really eager to learn (Timmins and Bryant in Semerci, 2005: 415).

In fact, effective problem solving is not only important for the survival of the community, but also important for the future of community prosperity (Mukhodhapayah, 2013: 21). Students are future citizens and the potential they have can significantly affect the nation's progress. Problem solving skills enable them to deal with various challenges that arise effectively. Therefore, developing student problem solving skills is one of the current needs. In line with Rini's opinion (2017: 1741) that problem solving skills is one of the basic abilities that must be possessed by every student, because students are part of the community who will certainly experience social problems so that when experiencing problems, of course problem solving skills are needed.

Problem solving is an activity carried out by each individual in identifying problems or problem situations, then giving a temporary answer or hypothesis after that from the hypothesis data collection or data collection will be carried out until it reaches the final stage of drawing generalizations. The problem solving approach in the learning process can provide a solid foothold for students to think effectively. Ahmad (2014: 2) revealed that one of the final objectives of the social studies learning process in elementary schools is that students have basic skills in solving problems. Educating students to have problem solving skills needs to be done from an early age, so that later when they are adults and in their environment, students do not feel confused to deal with the problem. If students do not have the ability to solve problems, then it is possible that students will solve the problem in the wrong way.

Consequently, schools must be able to go beyond verbalism in transferring knowledge, should provide experience in relation to how they apply outside of school. According to Purwadi (2014: 343) the use of the PBL model can help students in communicating that is conveying something they know through dialogue or mutual relations events that occur in the classroom environment, namely the transfer of messages in the form of concepts, or problem solving strategies. Also emphasized by Isrokijah (2015: 100) explains that PBL is considered as an instruction approach that will inspire students to develop thinking skills in problem solving and one type of student-centered model. PBL is an active learning model that supports flexibility and creativity in learning changing knowledge and considering individual differences. This is a learning method that makes students face to face with problems that they can encounter in the real world, which makes them aware of their own interests based on problem solving skills, and this focuses on student activities that depend on mastery and adequacy.

Students who are in the PBL learning environment have well-trained problem solving skills. As Giatri said (2014: 25), students who learn to use PBL demonstrate better clinical problem solving skills. Problems are considered to be one of the three key elements of PBL, problems must stimulate thinking or reasoning and lead to independent learning in students (Sockalingam \& Schimdt, 2011: 6). In addition, students can use all the abilities they have in problem solving efforts. According to Savery (2006: 12), in a learning environment PBL students work in collaborative groups to identify what they need to learn in order to solve problems.

Learning using the PBL model will prioritize students more actively, students' understanding of the concepts learned is clearer and have good problem solving skills, this is because understanding concepts and solving problems using PBL models is done through group discussions. An issue related to the subject in the lesson is given to students to be completed in groups. The problem chosen should have a conflict issue or controversial nature, the problem is important, urgent and can be solved (solutionable) by students. The researcher hopes that through this Problem Based Learning learning model each student can receive the information provided. Learning becomes easier and more enjoyable for children. All information that is processed in the brain through such a system makes it easy to learn, understand, and re-analyze precisely and efficiently. Based on the explanation above, the title of this research is "The Effect of Problem Based Learning Model on Understanding Concepts and Skills in Solving Problems in Learning Social Sciences in Grade IV Students of SDN 1 Mulung Driyorejo Gresik".

\section{METHODS}

The type of research carried out is experimental research with the design used is Quasi Experimental or quasi-experimental. The research design used in this study is Non Equivalent Control Group Design, namely the experimental group and the control group cannot be selected randomly or randomly (Sugiyono, 2008: 116).

Table 1. Research Design

\begin{tabular}{cccc}
\hline Class & Pre-test & Treatment & Pos-test \\
\hline $\mathrm{X}^{1}$ & $\mathrm{O}^{1}$ & $\mathrm{R}^{1}$ & $\mathrm{O}^{3}$ \\
\hline $\mathrm{X}^{2}$ & $\mathrm{O}^{2}$ & $\mathrm{R}^{2}$ & $\mathrm{O}^{4}$ \\
\hline
\end{tabular}

Information: 


\author{
$\mathrm{X}^{1}$ : Experimental Class \\ $\mathrm{X}^{2}$ : Control Class \\ $\mathrm{R}^{1}$ : Treatment is a problem based learning model \\ $\mathrm{R}^{2}$ : The treatment is a conventional model \\ $\mathrm{O}^{1}$ : Pre test experimental class \\ $\mathrm{O}^{2}$ : Pre test control class \\ $\mathrm{O}^{3}$ : Post test experimental class \\ $\mathrm{O}^{4}$ : Control class post test
}

This research was conducted in the fourth grade of SDN 1 Mulung, East Java, Indonesia with a population of all fourth grade students of SDN 1 Mulung in grades IVA, IVB, and IVC which totaled 75 students. The researcher chose the sample random sampling technique, in the sampling the researcher mixed the subjects in the population so that all subjects were considered the same. Data collection techniques using tests. Tests are used to measure concept understanding and problem solving skills in this study. The test is done twice, namely before the material is given (pre test) and after learning (post test).

Data analysis techniques in this study through several stages, namely analysis of items and analysis of test results. Butri analysis of the question through validity test using product moment correlation test analysis, then test reliability with spearman brown. For analysis of test results there are several tests, namely normality test, homogeneity test, and T-test test with the help of SPPS 22 application which has a provision that the significance value must be greater than 0.05 ( $\mathrm{Sig}>0.05$ ) so that the research data will be normal, and homogeneous. The normality test is used to determine whether the sample in the study is normally distributed both in the pre test and post test population values. Homogeneity test is used to determine the group variation between the experimental class and the control class is a homogeneous sample.

Then for the t-test, the statistical technique used to test the significance of the difference in 2 mean fruits derived from two distributions, in this t-test the significance value must be less than 0.05 so that there is an influence in the study or $\mathrm{Ha}$ is accepted. And the last test is to calculate the normalized N-Gain value to find out how much influence the use of the concept of time and the chronology of students.

\section{RESULTS AND DISCUSSION}

Table 2. Average Results Pre test and Post test

\begin{tabular}{lcccc}
\hline \multirow{2}{*}{ Class } & \multicolumn{2}{c}{ Understanding Concepts } & \multicolumn{2}{c}{ Problem Solving Skills. } \\
\cline { 2 - 5 } & Pre-test & Post-test & Pre-test & Post-test \\
\hline Control & 55,05 & 61,95 & 54,75 & 59,5 \\
\hline Experiment & 55,4 & 85,25 & 53,5 & 85,75 \\
\hline
\end{tabular}

Based on the average results obtained from the two classes in table 2 shows that the average test results at the end of the experimental class are higher than the results of the average test at the end of the control class. After obtaining the average results of the two groups, the next step is to analyze the test results as follows:

\subsection{T-test Experimental Class Post-Test and Control Class Post-Test}

Independent-Sample analysis t-test of the experimental class post-test and control class post-test was conducted to determine whether there were significant differences in the post-test scores in the two classes. The following are the results of $t$ test analysis:

Table 3. Test results of Post-test Understanding of Concepts of Experimental Classes and Control Classes

\begin{tabular}{|c|c|c|c|c|}
\hline \multicolumn{5}{|c|}{ Independent Samples Test } \\
\hline & & & \multicolumn{2}{|c|}{ HASIL PENILAIAN } \\
\hline & & & $\begin{array}{c}\text { Equal } \\
\text { variances } \\
\text { assumed }\end{array}$ & $\begin{array}{c}\text { Equal } \\
\text { variances not } \\
\text { assumed }\end{array}$ \\
\hline \multirow{2}{*}{$\begin{array}{l}\text { Levene's Test for Equality } \\
\text { of Variances }\end{array}$} & \multicolumn{2}{|l|}{$F$} & 1.855 & \\
\hline & \multicolumn{2}{|l|}{ Sig. } & .181 & \\
\hline \multirow{7}{*}{$\begin{array}{l}\text { t-test for Equality of } \\
\text { Means }\end{array}$} & \multicolumn{2}{|l|}{$t$} & 7.329 & 7.329 \\
\hline & \multicolumn{2}{|l|}{$d f$} & 38 & 34.573 \\
\hline & \multicolumn{2}{|l|}{ Sig. (2-tailed) } & .000 & .000 \\
\hline & \multicolumn{2}{|l|}{ Mean Difference } & 23.300 & 23.300 \\
\hline & \multicolumn{2}{|l|}{ Std. Error Difference } & 3.179 & 3.179 \\
\hline & \multirow{2}{*}{$\begin{array}{l}95 \% \text { Confidence Interval } \\
\text { of the Difference }\end{array}$} & Lower & 16.864 & 16.843 \\
\hline & & Upper & 29.736 & 29.757 \\
\hline
\end{tabular}

that the average results of the experimental class were 85.25 and the mean of the control class was 61.95 , so it was concluded that the average experimental class was greater than the control class. From table 3 the significance value $(0,000<0,05)$, means that there are differences in the scores of the results of students' conceptual understanding significantly in both classes.

Table 4. Test Results t Post-test Skills for Solving Experiment Class Problems and Control Classes

Independent Samples Test

\begin{tabular}{|c|c|c|c|c|}
\hline & & & \multicolumn{2}{|c|}{ HASIL PENILAIAN } \\
\hline & & & $\begin{array}{c}\text { Equal } \\
\text { variances } \\
\text { assumed }\end{array}$ & $\begin{array}{c}\text { Equal } \\
\text { variances not } \\
\text { assumed }\end{array}$ \\
\hline \multirow{2}{*}{$\begin{array}{l}\text { Levene's Test for Equality } \\
\text { of Variances }\end{array}$} & \multicolumn{2}{|l|}{$\mathrm{F}$} & 1.431 & \\
\hline & \multicolumn{2}{|l|}{ Sig. } & .239 & \\
\hline \multirow{7}{*}{$\begin{array}{l}\text { t-test for Equality of } \\
\text { Means }\end{array}$} & \multicolumn{2}{|l|}{ t } & 10.536 & 10.536 \\
\hline & \multicolumn{2}{|l|}{ df } & 38 & 34.668 \\
\hline & \multicolumn{2}{|l|}{ Sig. (2-tailed) } & .000 & .000 \\
\hline & \multicolumn{2}{|l|}{ Mean Difference } & 26.250 & 26.250 \\
\hline & \multicolumn{2}{|l|}{ Std. Error Difference } & 2.491 & 2.491 \\
\hline & \multirow{2}{*}{$\begin{array}{l}95 \% \text { Confidence Interval } \\
\text { of the Difference }\end{array}$} & Lower & 21.206 & 21.190 \\
\hline & & Upper & 31.294 & 31.310 \\
\hline
\end{tabular}

The post-test t-test for problem solving skills revealed that the average results of the experimental class were 85.75 and the mean results of the control class were 59.5, so it was concluded that the average results of solving the experimental class were greater than the control class. From table 4, the significance of the significance value $(0,000<0,05)$ means that there are differences in the score 
of the results of solving the problems of students in both classes.

\subsubsection{N-Gain Test Normalized}

The n-gain calculation is done to see the effect of the problem based learning model on improving concept understanding and problem solving skills. The following table shows the results of N-Gain calculations:

Table 5. N-Gain Test Results Normalized Concept Understanding

\begin{tabular}{ccc}
\hline Class & N-Gain Skor & Category \\
\hline Control & 0,1 & Low \\
\hline Experiment & 0,7 & Middle \\
\hline
\end{tabular}

From table 5 it is known that the N-Gain score in the control group is 0.1 low category, and the experimental group score is 0.7 in the moderate category, based on the results obtained above, it can be concluded that the mastery of concepts in the experimental class is higher than the control class.

Table 6. N-Gain Test Results Normalized Problem Solving Skill

\begin{tabular}{ccc}
\hline Class & $\mathrm{N}$-Gain Skor & Category \\
\hline Control & 0,1 & Low \\
\hline Experiment & 0,8 & High \\
\hline
\end{tabular}

From table 6 it is known that the N-Gain score in the control group is 0.1 low category, and the experimental group score is 0.8 in the moderate category, based on the results obtained above, it can be concluded that the mastery of concepts in the experimental class is higher than the control class.

\subsubsection{The Effect of Problem Based Learning Model on Understanding Student Concepts}

Based on the description that has been explained in the results of the study, the researcher conducted a discussion of the research on the findings from the analysis of test data mastery concepts and problem solving skills. The research was carried out through the learning process in the experimental class and the control class that had been designed in such a way as to use learning tools and research instruments.

In this discussion, we will discuss the effect of using the problem based learning model on understanding the concepts in social studies learning in the fourth grade of SDN 1 Mulung. The data obtained from the results of the study are quantitative data from the results of the pre-test and post-test to determine the students' ability to understand concepts. The learning process carried out both in the experimental class and in the control class was conducted during 2 meetings. Geographical material used in this study is material about natural resources and their use in daily life. Thus, in this study students are expected to be able to understand the concept well.
Concepts are the main points of a series of relationships and ideas and all the other things that are associated with it. In other words, before we reveal the material further, we must master or understand the concepts that exist in the material (Tanoe, 2004: 50). Understanding the concept can be done in two ways, namely arranging information in one main theme along with the main points and developing a chart of concepts that describe the central theme along with related concepts, interrelated relations. In this case, understanding concepts can be obtained through the application of learning using problem based learning learning models in the experimental class.

So that in this study learning a concept will be developed by knowledge that has to do with facts from various data which includes events, landscapes, objects or known symptoms. Students will be able to conceptualize and develop their own concepts not only understand the name of a concept. The concept will help students organize data into patterns that can provide meaningful mastery of the data. In this study, the researcher provides an interrelated category where the evidence will be collected from the data or from the experience of the students themselves.

Research conducted during 2 meetings or learning in both classes was conducted so that there are no factors that disrupt the process of research in both groups so that it can produce a maximum result. When the teacher carries out learning activities about concepts, students can associate a number of examples and not examples of known geographic concepts so that students fully and comprehensively understand the concepts learned. The benefits obtained by students in learning the concept that students are able to classify both in the form of characteristics and differences in a group, explain something that is considered complicated or need detailed information and is able to conceptualize things carefully through symbol-sombol (Suparda, 2013: 54).

This statement can be proven through this research. For example, in learning the concept of natural resources can be updated. Students will classify objects that are included and not included in the concept. Students understand the meaning, mention examples and not examples, classify them and in learning the teacher also shows some images of an object to support concept learning. Therefore, through this study students can easily understand the concepts obtained through effective, fun, and meaningful learning activities so that IPS material that is considered boring can be studied with fun.

In this study the problem based learning model is considered a good model and is able to simplify the concept of geographic material that is natural resource material which is one of abstract material, so the problem based learning model is used to simplify and concretize the material so that mastery of student concepts increases. The use of a problem based learning model that is fun and 
in accordance with basic competencies and learning indicators is one of the reasons researchers use the model.

In this study students find out what happened, manipulate objects, symbols, ask questions and try to find their own answers, match what they find at other times, and compare their findings with the findings of other students, while the teacher only directs and guides students in learning and formulating their knowledge. The teacher provides motivation so that the learning process runs effectively, so that learning objectives can be achieved.

This is in line with several previous studies that are relevant to this study. The study was conducted by Syahroni Ejin in 2016 on fourth grade students of the elementary school entitled "The Influence of Problem Based Learning (PBL) Model on Understanding Concepts and Critical Thinking Skills of Class IV Students of Guava Downstream Baluti 2 in Natural Sciences". This study shows that the use of the problem based learning model influences and enhances the ability of students to understand concepts and critical thinking skills compared to those using the direct learning model.

In the research that has been carried out there are also some limitations including: (1) the limitation of the research location is that the research is only limited to one place, namely SDN 1 Mulung Driyorejo Gresik whose population is limited to 40 students so if samples are taken there may be different results if implemented in schools with a greater population of class IV, (2) limited material, namely learning material in this study focused only on natural resource material, it allows different results of research to occur if research is carried out on other learning materials, and (3) limitations ability, that is, the researcher realizes that researchers have limited abilities, especially in the scientific field, but researchers will try their best to understand with guidance from experts.

This shows that not all variables can be strictly controlled. Therefore, if this research is conducted with different variables it will be able to allow different research results. Although many limitations were found in this study, the authors are grateful that this research can be resolved smoothly. Various kinds of limitations above can be overcome during the implementation of research so that research continues in accordance with predetermined planning and from all the explanations described above, it can be interpreted that social studies learning using the problem based learning model has a significant influence on understanding concepts and problem solving skills.

\subsubsection{The Effect of Problem Based Learning Model on Problem Solving Skill}

Based on the description that has been explained in the results of the study, the researcher conducted a discussion of the research on the findings from the results of the data analysis test for problem solving skills. The research was carried out through the learning process in the experimental class and the control class that had been designed in such a way as to use learning tools and research instruments. In this discussion, we will discuss the effect of using the problem based learning model on problem solving skills in social studies learning in the fourth grade of SDN 1 Mulung.

The learning process carried out both in the experimental class and in the control class was conducted during 2 meetings. Geographical material used in this study is material about natural resources and their use in daily life. Thus, in this study students are expected to improve their skills in solving problems.

Students as citizens of the future and the potential they have will significantly affect the nation's progress. Problem solving skills enable them to deal with various challenges that arise effectively. Confirmed by Rini (2017: 1741) that problem solving skills is one of the basic abilities that must be possessed by every student, because students are part of the community who will certainly experience social problems so that when experiencing problems of course problem solving skills are needed.

Besides that, after this research was carried out it was proven that a theory related to the results of the study was in harmony with research. The related theory put forward by John Dewey who describes the view of education with schools as a mirror of a larger society and class will be a laboratory for investigating and overcoming real life problems. Dewey Pedagogy encourages teachers to engage students in problem-oriented projects and help them investigate important social and intellectual problems. Learning in school should be purposeful and not abstract. Purposeful and problem centered vision learning supported by students' innate desire to explore situations that are personal.

Gijselaers (in Isrokijah, 2015: 100) explains that PBL is based on the view of learning as a process in which students actively build knowledge. This can help students well, because each student can work at different speeds according to their abilities. PBL can help students in communicating that is conveying something that they know through dialogue or mutual relations that occur in the classroom environment, namely the transfer of messages in the form of concepts, or strategies for solving a problem. According to Savery (2006: 9), PBL is student-centered, empowers students to conduct research, integrates theory and practice, and applies knowledge and skills to develop appropriate solutions for defining problems, PBL is an instructional approach.

This is in line with several previous studies that are relevant to this study. This research was conducted by Kustiyo Rini in 2017 in grade IV elementary school students entitled "The Effect of Using the Problem Based Learning Model on problem-solving ability of fourth grade students of Krembung Keret SDN". This study shows that the application of the problem based learning model is able to improve problem-solving skills so that social studies learning outcomes are better than those using 
direct learning models.

In addition, the same research conducted by Khuroidah Asna in 2013 on students of class XI IPS MAN 3 Tulungagung about "Increasing the Ability to Solve Problems and Geography Learning Outcomes through Problem Based Learning Learning Models" has been proven that the use of problem based learning models can improve problem solving skills and social studies learning outcomes of students of class XI IPS. Some of these studies are relevant to this study.

In the research that has been carried out there are also some limitations including: (1) the limitation of the research location is that the research is only limited to one place, namely SDN 1 Mulung Driyorejo Gresik whose population is limited to 40 students so if samples are taken there may be different results if implemented in schools with a greater population of class IV, (2) limited material, namely learning material in this study focused only on natural resource material, it allows different results of research to occur if research is carried out on other learning materials, and (3) limitations ability, that is, the researcher realizes that researchers have limited abilities, especially in the scientific field, but researchers will try their best to understand with guidance from experts.

This shows that not all variables can be strictly controlled. Therefore, if this research is conducted with different variables it will be able to allow different research results. Although many limitations were found in this study, the authors are grateful that this research can be resolved smoothly. Various kinds of limitations above can be overcome during the implementation of research so that research continues to run according to predetermined planning and from all the explanations described above, it can be interpreted that social studies learning using the problem based learning model has a significant influence on problem solving skills.

\section{CONCLUSION}

Based on our review and study result, there are some influences that found. The n-gain obtained by the two classes, namely the understanding of the experimental class concept get a gain value of 0.7 with a moderate category and the control class gets an n-gain value of 0.1 with a low category. Thus it can be concluded that there is a large and significant influence on social studies learning by using the use of problem based learning models to understand the concept in grade fourth on Mulung Elementary School.

While the $\mathrm{n}$-gain value for problem solving in the experimental class is 0.8 with a high category and the control class gets a n-gain value of 0.1 with a low category. Thus it can be concluded that there is a large and significant influence on social studies learning by using the use of a problem based learning model for problem solving skills in grade IV fourth on Mulung Elementary School.

\section{REFERENCES}

Ahmad. (2014). Application of Problem Based Learning Models to Improve Students' Online Problem Solving Abilities (online). JUPENDAS, ISSN: 2355-3650, Vol. 1, No.1

Andriansen, Hanne Kristine. Timeline Interviews: A Tool for Conducting History Research. Vol.3(1):pp40-55

Ejin, Syahroni. 2016. The Effect of Problem Based Learning Model on Understanding Concepts and Critical Thinking Skills of Class IV Students at Jambu Hilir Baluti 2 in Natural Sciences. Education Journal. Vol.1, No.1, pp: 65-71

Giarti, Sri.2014. Skills Improvement of the Problem Solving Process and Mathematics Learning Outcomes Using the PBL Model Integrated Authentic Assessment in Class VI Students of SDN 2 Bengle, Wonosegoro. Scholaria. Vol.4, No. 3, pp. $13-27$

Isrokijah. (2015). Developing Problem Based Learning $(P B L)$ Worksheets for the Eight Grade Students at Junior High School (online). LLT Journal, Vol. 18, No. 2, ISSN 1410-7201

Khuroidah, Asna dkk. 2013. . Increased Ability to Solve Problems and Results of Learning Geography Through Problem Based Learning Learning Models. Vol. 9, No. 4: 25-30

Mukhopadhyay, R. 2013. Problem Solving In Science Learning-Some Important Considerations of a Teacher. IOSR Journal of Humanities And Social Science. Vol. 8, No. 6: 21-25

Muliyono, Rizqi. M. 2017. Use of Media Timeline to Improve Mastery of the Concept of Time and Chronology in Social Studies Learning in Grade IV Elementary School Students. JPGSD Unesa. Vol.5, No.3, pp. 510-522

Purwadi, Ricky Ekarisky. 2014. Application of Problem Based Learning in Developing Communication Skills in Science Learning. Journal of STKIP Siliwangi MIPA Education. Vol.2, No.1

Rahmadani, Hanifa, danArrofa Acesta. 2017. . Effect of Application of Problem Based Learning Learning Models to Understanding Student Concepts. Journal of Basic Education. Vol.2, No.1,pp:1-9

Savery, John R. (2006). Overview of Problem Based Learning: Definitions and Distinctions (online). Interdisciplinary Journal of Problem-Based Learning, Volume 1, Issue 1, Article 3

Semerci, Nuriye. 2005. The Effects of Problem Based Learning on the Academic Achievement of Students in Development and Learning. International Journal of Educational Reform. Vol. 14, No. 4, pp.415-425

Sockalingam, N. \& Schmidt, H. G. (2011). Characteristics of Problems for Problem Based Learning: The Students Perspective (online). Interdisciplinary Journal of Problem-Based Learning, Volume 5, No. 1, 
p. 6-33

Sugiyono. 2014. Quantitative, Qualitative Research and R \& D Methods Bandung: Alfabeta

Suparda. 2013. Introduction to Social Sciences. Jakarta: Bumi Aksara

Susanto, A. 2011. Theories of Learning and and Learning in Primary Schools. Jakarta: Prenamedia Group

Tanoe, Silvester Petrus. 2004. Social Studies in Elementary School. Jakarta: Ministry of National Education 